\title{
OBRANA GRAĐEVINSKIH KONSTRUKCIJA OD POTRESA POSTUPKOM IZOLACIJE - BUDUĆNOST ILI UTOPIJA
}

\author{
Senka Mitrović \\ Sveučilište J. J.Strossmayera u Osijeku, Građevinski fakultet Osijek, student \\ Darko Meštrović \\ Sveučilište u Zagrebu, Građevinski fakultet Zagreb, prof.dr.sc. \\ Dragan Morić \\ Sveučilište J. J.Strossmayera u Osijeku, Građevinski fakultet Osijek, prof.dr.sc.
}

Sažetak: Ovaj rad sažeti je prikaz postupka seizmičke izolacije građevinskih konstrukcija, argumentiran kratkim prikazom provedenih seizmičkih analiza. Dio je diplomskog rada studentice Senke Mitrović, obranjenog u listopadu 2005. godine na Građevinskom fakultetu Osijek. Hoće li jednog dana ovaj način zaštite građevinskih konstrukcija postati uobičajen u inženjerskoj praksi u Hrvatskoj (kao u nekim slučajevima danas u Japanu) ili je u pitanju samo postupak zasnovan na teoriji dinamike konstrukcija, pokazat će vrijeme. Osim osnova na kojima se zaštita zasniva prikazan je i kratki dio numeričkog postupka provedenog za armiranobetonsku okvirnu konstrukciju tlocrtne površine 30x18 metara i visine 18 metara.

Ključne riječi: potres, seizmička analiza, seizmička zaštita, izolacija, konstrukcija na elastičnim ležajevima

\section{DEFENDING OF BUILDING STRUCTURES FROM EARTHQUAKES BY ISOLATION PROCEDURE - FUTURE OR UTOPIA}

\begin{abstract}
In this paper procedure of the seismic isolation of structures with appropriate seismic analyses are presented. Paper is a part of the B.Sc thesis of student Senka Mitrovic from October 2005. made at the Faculty of Civil Engineering in Osijek. There is no one case of seismic isolation protection of structure in Croatia today. Is it only on the theory of structural dynamics based procedure or there is any chance of its application in practice, time will show.

First part of paper shows elemental and based theoretical analysis on which the protection with isolators is based. After that the reinforced concrete frame construction layout area of $30 \times 18$ meters and a height of 18 meters was analysed with and without seismic base isolator protection.
\end{abstract}

Key words: earthquake, seismic analysis, seismic protection, isolators, structure on elastic isolators 


\section{Aseizmička zaštita nosive konstrukcije građevine općenito}

Zaštita građevina od potresa može se zasnivati na unaprijed osiguranoj kontroli ponašanja građevine za vrijeme dinamičkog djelovanja kakvo je potres. Primijenjeni postupci mogu se klasificirati po sljedećim principima:

prema principu dinamike, po načinu realiziranja i prema mjestu instalacije, kako slijedi:

Klasifikacija prema principima dinamike:

Metoda kontroliranja i reguliranja karakteristika povratne sile

Metoda kontroliranja i reguliranja prigušenja

Metoda kontroliranja i reguliranja mase

Klasifikacija prema načinu realizacije

Pasivni način

Aktivni način

Klasifikacija prema mjestu instalacije

Vanjski tip

Unutarnji tip

Principi dinamike se ostvaruju kontrolom i regulacijom karakteristika "ulazne" sile, kontrolom i regulacijom prigušenja i regulacijom veličina i položaja masa po konstrukciji (slika 1).

a
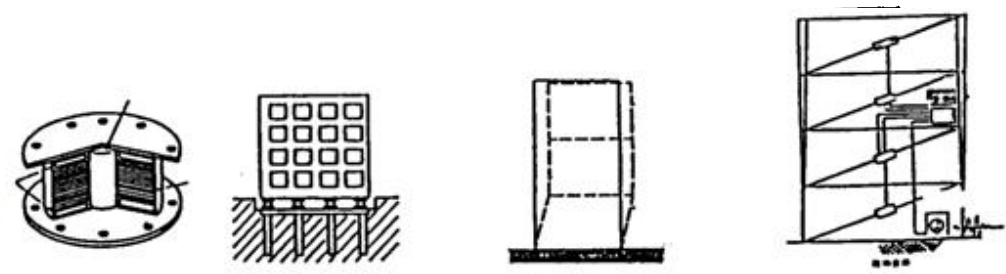

b
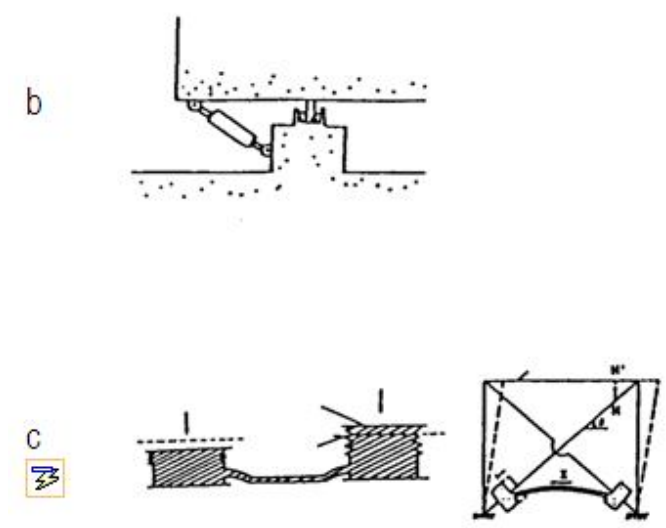
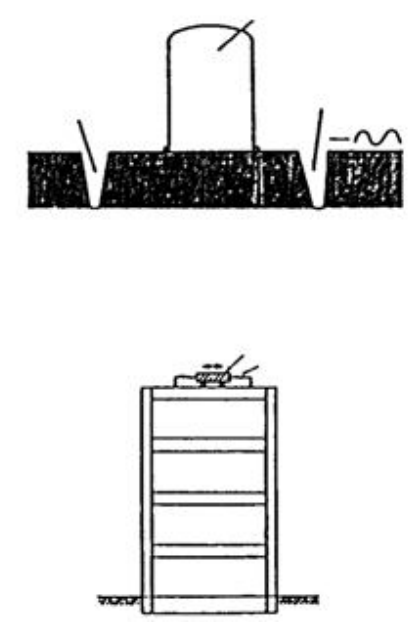

\section{Slika 1 - Primjeri kontrole i regulacije sile (a), prigušenja (b) i položaja i rasporeda mase (c)}

Prema načinu realizacije, u osnovi, razlikuju se dva koncepta aktivni i pasivni. Koncept aktivne kontrole deformacija građevine postiže se umetanjem elektronički upravljivih hidrauličkih uređaja, tj. termin „aktivni“ znači unošenje vanjske energije u dinamički sustav.

Pasivni koncept zasnovan je na zahvatima koji ne dovode eksternu energiju u sustav ali sustav čine različitima od konvencionalne građevine.

Prema mjestu intervencije razlikujemo zahvat unutar konstrukcije i izvan nosive konstrukcije (slike 2 i 3 ). 

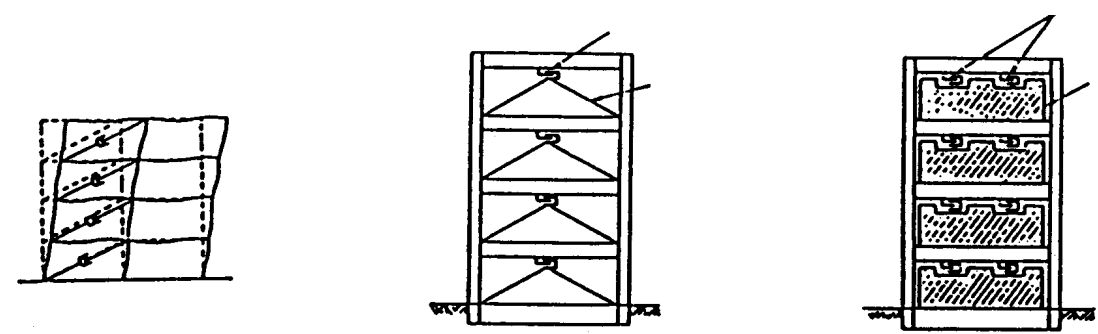

Slika 2 - Zahvat na elementima nosive konstrukcije građevine

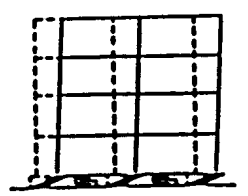

\section{Slika 3 - Zahvat izvan nosive konstrukcije građevine}

Aktivni pristup s vanjskim tipom instalacije, tj. postavljanje specijalnih naprava, najčešće elektronički upravljivih hidrauličkih uređaja, složen je i nadasve skup zahvat. Ekonomski i složeni tehnički uvjeti realizacije ovakvog koncepta čine ga vrlo teško prihvatljivim i za zemlje bitno bogatije od Hrvatske.

Pasivni pristup s unutarnjim tipom instalacije najčešće se zasniva na viskoelastičnom ponašanju specijalnih uređaja za prigušivanje koji su ugrađeni u konstrukciju. Cilj im je disipacija energije i zaštita elemenata konstrukcije od plastifikacije i oštećenja. I ovaj koncept je skup i rijetko zastupljen pri zaštiti od potresa realnih građevina i u bogatijim zemljama.

U ovom radu govori se o postupku koji je u svijetu inženjerski najprimjenjivaniji način zaštite građevina od potresa. Radi se o postupku izolacije nosive konstrukcije na lameliranim gumenim ležajevima (izolatorima) (slika 3). Ovaj postupak prema principima dinamike regulira karakteristiku ulazne i povratne sile, prigušenje i period sustava, prema načinu realizacije jest pasivan, a prema mjestu instalacije je vanjski zahvat.

\section{Izoliranje baze nosive konstrukcije}

Izoliranje nosive konstrukcije građevine od tla kojim se šire potresni L i R valovi s horizontalnim i vertikalnim komponentama pomoću lameliranih gumenih ležajeva izvodi se duž jedne horizontalne ravnine koja dijeli konstrukciju na dva dijela. Najčešće je to podjela na gornji i donji ustroj.Na tim mjestima se ugrađuju elastični i/ili elastoplastični izolatori potresa koji u horizontalnom smjeru imaju vrlo nisku a u vertikalnom visoku vrijednost krutosti. Kod armiranih elastomera taj je odnos 1:400. Horizontalno „mekani“ ležajevi smanjuju vlastitu frekvencija osnovnog oblika osciliranja. Nadalje se karakteristikama sila-deformacije izolatora ili također ugradnjom eksternih prigušivača u ravnini izolacije postiže visoka vrijednost prigušenja.

\subsection{Tipovi izolatora baze}

Danas se kao izolatori baze najviše koriste elastomerni lamelirani ležajevi. Imaju efekt opruge koja pomaže da se konstrukcija vrati u prvobitni položaj. To su deformabilni elementi koji se koriste za prijenos opterećenja s jednog dijela konstrukcije na drugi. Uz relativno male troškove proizvodnje i jednostavnu ugradnju optimalno se primjenjuju u mostogradnji, visokogradnji i industrijskim objektima. Mogu biti armirani (AEL) i nearmirani (NEL). AEL sadrže armaturu od čeličnih limova visoke čvrstoće koji se toplinskom vulkanizacijom spajaju sa slojevima elastomernog materijala. Čelični limovi su sa svih strana obloženi elastomerom i tako zaštićeni od korozije. Elastomeri se proizvode od sintetskog kloroprenkaučuka koji je otporan na starenje pod djelovanjem atmosferskih utjecaja. Nosivost ležaja u pogledu horizontalne sile je ograničena. Pomaci i zaokreti ostvaruju se deformacijom 
kaučuka. Ugrađeni djeluju kao izolatori građevine a ujedno povećavaju osnovni vlastiti period (T-strategija). Na taj način se doseže zona seizmičkog spektra karakterizirana zadržavanjem niske energije. Daju neznatno prigušenje i, ugrađeni u konstrukciju s pokretnim ležajevima, djeluju kao povratni "feder". Kod elastomera produženje perioda izolatora postiže se povećanjem visine.

Elastomerni ležajevi omogućuju istovremene pomake u dva okomita smjera i istovremena zakretanja u tri okomite ravnine a preuzimaju vertikalna (normalna) i horizontalna (posmična) opterećenja (naprezanja).

Oni su tlocrtno u pravilu pravokutni ili okrugli. Armirani ležajevi se proizvode prema standardnim veličinama, a po specijalnoj narudžbi mogu se proizvoditi i u drugim veličinama. U tom slučaju debljina sloja elastomera i debljina čeličnih limova odgovaraju debljinama najbližeg po površini manjeg ležaja standardne veličine. Tipovi elastomernih ležajeva prikazani su na slici 4.

\section{Tip 1}

Neusidreni elastomerni ležaj

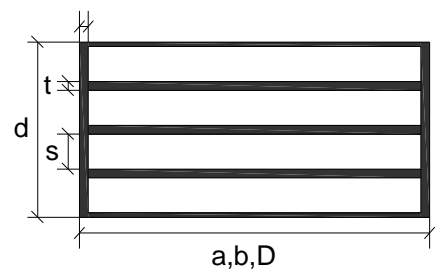

Tip 4

Usidreni u svim smjerovima pomični elastomerni ležaj Usidrenje pomoću okruglih ploča moždanika

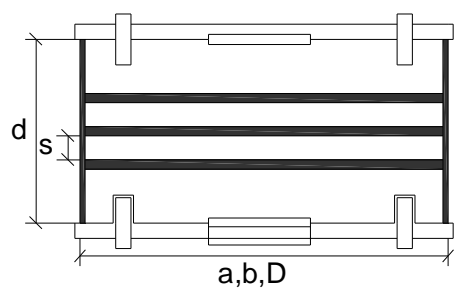

Tip 2

Usidreni u svim smjerovima pomični elastomerni ležaj Usidrenje pomoću trnova ili vijaka

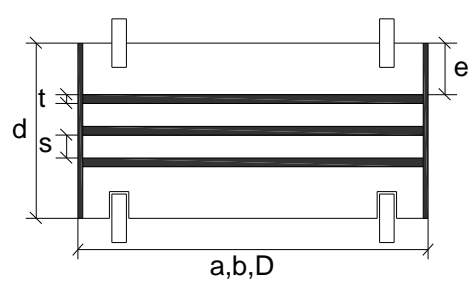

Tip 5

Usidreni u svim smjerovima pomični elastomerni ležaj Usidrenje pomoću suznog rebrastog lima

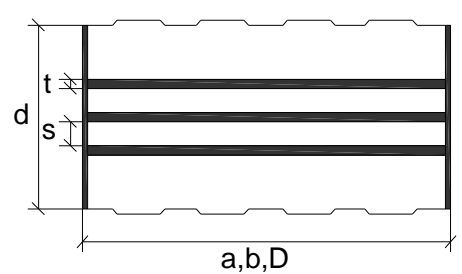

Slika 4 - Tipovi elastomernih ležajeva

Za vrijeme opterećivanja na ležajeve mogu djelovati normalna sila, posmične sile u pravcu dvije osi i moment savijanja oko dvije osi. Zbog prisilnih posmičnih deformacija ležajeva nastaju horizontalne sile. Na osnovi zaokretanja konstrukcije određuje se zaokretanje ležajeva. Osnovni zahtjev je da na rubovima ne dođe do odizanja ležajeva.

\subsection{Seizmički odziv izoliranih građevina}


Konvencionalne metode proračuna odziva zasnovane su na pretpostavci prijenosa gibanja tla u konstrukciju. Dinamička svojstva konstrukcije (krutost, masa, prigušenje), kao i nosivost i duktilnost elemenata konstrukcije elementi su seizmičke analize odziva, anvelope sila i postupka dimenzioniranja.

Izolacija baze konstrukcije ima za cilj ograničiti nivo seizmičkih sila u elementima nosive konstrukcije. Nosivost i duktilnost te krutost i prigušenje nosive konstrukcije, postaju nevažni. Građevina, tj. njena masa u proračunu postaje de facto „kruto tijelo“, a pojmovi krutost, prigušenje, poslijeelastično ponašanje i duktilnost su usmjereni na ležajne elemente.

Kod konvencionalne metode događa se disipacija energije unutar nosivog sistema kroz stvaranje plastičnih zglobova, te se javljaju mjestimična oštećenja. Upotrebom eksternih disipatora energije krutost građevine se održi nakon potresa. Odnos sila-deformacija takvih uređaja je jasno definiran. One ostaju pod ponovljenim cikličnim naprezanjima konstantne.

Kod konvencionalnih metoda, povećanje perioda građevine kroz nastajanje plastičnih zglobova i opadanje krutosti građevine, slika su oštećenja konstrukcije. Izoliranjem konstrukcije, štete se minimaliziraju. Nosivost i duktilnost ležajeva, naročito ona posmična, postaju bitne u analizi oštetljivosti.

Kako je prikazano na slici 5, produljenje perioda sustava reducira ubrzanje i zbog toga su potresom izazvane sile u konstrukciji manje, ali se deformacije znatno povećavaju. To je deformacija izoliranog sistema. Povećanjem prigušenja smanjuje se deformacija. Prigušenje je korisno dalje u reduciranju sila u konstrukciji $\mathrm{i}$ deformacije izoliranog sistema. Zajednički sistem tog tipa koristi cilindrične ležajeve sa slojevima čelične ploče i tvrde gume. Prigušenje gume je malo pa je dodatno prigušenje osigurano mehaničkim prigušivačem. Ovom pristupu pripadaju lamelirani ležajevi i ležajevi s olovnom jezgrom.

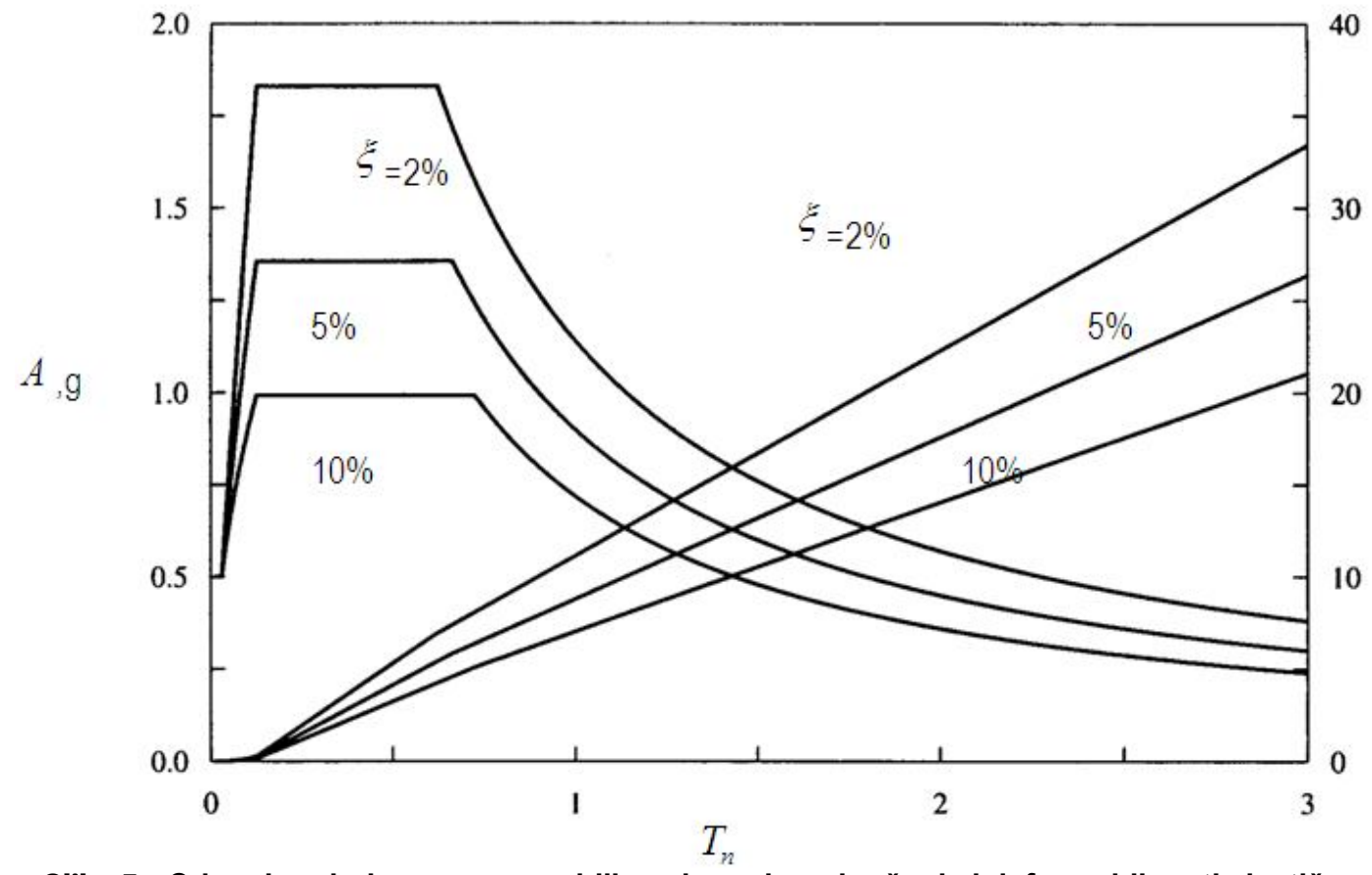

Slika 5 - Odnosi perioda osnovnog oblika, ubrzanja, prigušenja i deformabilnosti elastičnog sustava

Drugi tip izolacijskog sistema čine valjci i klizači između temelja i konstrukcije. Poprečna sila koja se unosi u konstrukciju preko izoliranog sloja ograničena je očuvanjem niskog koeficijenta trenja. Trenje mora biti dovoljno visoko da se odupre jakom vjetru i malom potresu bez klizanja. U tom tipu izolacijskog sistema klizni pomak se reducira visko-vlačnom oprugom ili konkavnom površinom valjka. Ti mehanizmi osiguravaju povratne sile za povratak konstrukcije u njen ravnotežni položaj. Vrlo je složen postupak proračuna odziva konstrukcija izoliranih valjkastim kliznim izolatorima jer je proces klizanja nelinearan.

\subsection{Seizmički odziv izoliranih građevina}


Promatra se učinkovitost djelotvornosti izoliranja baze u redukciji sila izazvanih potresom. Izolirani sloj se nalazi između konstrukcije i tla. Izolirani sistemi su nelinearni u njhovom odnosu sila-deformacija međutim za dobivanje uvida u dinamičko izoliranje dovoljna je linearna analiza.

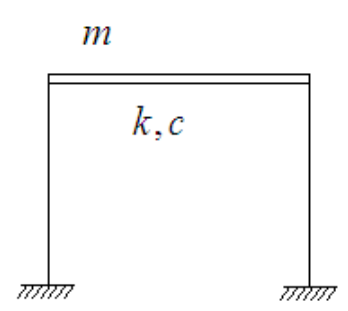

Slika 6a - Konstrukcija s fiksnom bazom

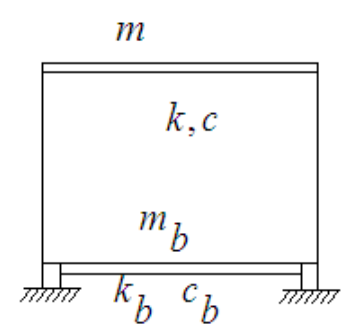

Slika 6b - Izolirana konstrukcija

Indeksom $f$ obilježeni su izrazi građevine s upetom (fiksnom) bazom. Ta konstrukcija ima sljedeće vrijednosti frekvencije, perioda osnovnog tona i prigušenja:

$$
\omega_{f}=\sqrt{\frac{k}{m}} \quad T_{f}=\frac{2 \pi}{\omega_{f}} \quad \xi_{f}=\frac{c}{2 m \omega_{f}}
$$

Građevina je postavljena na baznu ploču mase $m_{b}$, krutosti $k_{b}$ i viskoznog prigušenja $c_{b}$. Dva parametra $T_{b}$ $\mathrm{i} \xi_{\mathrm{b}}$ predstavljaju izolirani sistem.

$$
T_{b}=\frac{2 \pi}{\omega_{b}} \quad \omega_{b}=\sqrt{\frac{k_{b}}{m+m_{b}}} \quad \xi_{b}=\frac{c_{b}}{2\left(m+m_{b}\right) \omega_{b}}
$$

Prigušenje u kombiniranom sistemu je neklasično jer postoji razlika između visokog prigušenja u gumenim ležajevima i niskog prigušenja u građevini. Analiza takvog sistema s neklasičnim prigušenjem traži numeričku soluciju za spajanje jednadžbi kretanja. Modalna analiza nije primjenjiva za neklasične prigušene sisteme ali može osigurati približne vrijednosti. Dvostupanjskoj građevini koja je definirana sa m, k i c određeni su period i oblici, a za razumjevanje dinamičkog izoliranja baze rezultati su uspoređeni sa sistemom koji ima

$$
m_{b}=2 m / 3, T_{f}=0.4 s, T_{b}=2.0 s, \xi_{f}=2 \%_{i} \xi_{b}=10 \% \text {. }
$$

Posmična sila $u$ donjoj etaži $V_{b}$ i pomak baze $u_{b}$ određeni su korištenjem elastičnog spektra. Veća vrijednost prigušenja se uzima zbog dodatne disipacije do javljanja oštećenja očekivanog u konvencionalnim konstrukcijama pri duljem kretanju za vrijeme potresa. Izolacija konstrukcije je nastojanje reduciranja sile pridate konstrukciji do te granice da ne oštećuje konstrukciju ili nekonstruktivne elemente i tada je primjenjiva niža vrijednost prigušenja. Periodi i oblici su prikazani na slici 7.

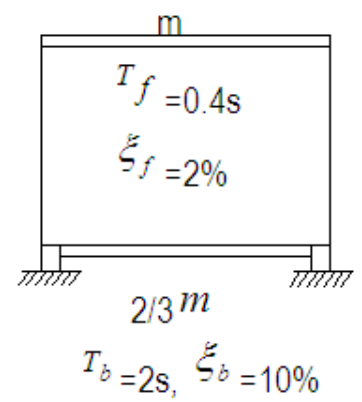

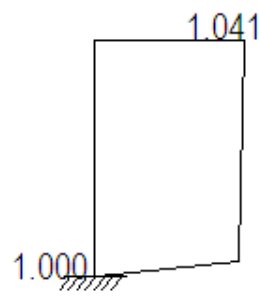

$T_{1}=2.024 \mathrm{~s}$

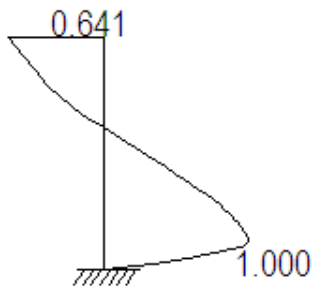

$T_{2}=0.250 \mathrm{~s}$

Slika 7 - Izolirana građevina, oblici i periodi 
Prvi oblik izolatora pretrpi deformaciju ali konstrukcija se ponaša kruto. Taj oblik nazvan je izolacijski oblik. Period tog oblika iznosi $T_{1}=2,024 \mathrm{~s}$ i približan je periodu izolirane baze $T_{b}=2,0 \mathrm{~s}$. Promijenjen je neznatno zbog fleksibilnosti konstrukcije. Drugi oblik obuhvaća deformaciju konstrukcije. Period mu je $T_{2}=0,25 \mathrm{~s}$ i znatno je kraći od perioda fiksne baze $\mathrm{T}_{\mathrm{f}}=0,4 \mathrm{~s}$. Dakako za ukupnu silu veći utjecaj ima prvi oblik. Modalni odnos prigušenja je određen jednadžbom

$$
\xi_{n}=\frac{C_{n}}{2 M_{n} \omega_{n}}
$$

i za prvi oblik iznosi $\xi_{1}=9,65 \%$, a za drugi $\xi_{2}=5,06 \%$. Prigušenje prvog oblika je blizu vrijednosti prigušenja izoliranog sistema. Do porasta prigušenja u konstrukciji od $2 \%$ na $5.06 \%$ dolazi jer je prigušenje u sistemu neklasično. Rezultati iznose: ukupna deformacija $u_{b}=35 \mathrm{~cm}$ a posmična sila $V_{b}$ iznosi $36.5 \%$ težine građevine. Poprečna sila u dnu je mnogo veća ako konstrukcija nije izolirana. Konstrukcija s periodom $T_{f}=0,4 \mathrm{~s} \mathrm{i} \xi_{f}=2 \%$ ima poprečnu silu u dnu $183 \%$ težine građevine. Izolirani sistem reducira silu jer je period prvog tona znatno veći od perioda osnovnog oblika neizolirane konstrukcije.

Sila u građevini i deformacija izoliranog sistema mogu biti procijenjene jednostavnom analizom tretiranjem građevine kao krute. Aproksimacija rezultata daje dobre rezultate u slučaju kada je period izoliranog sistema mnogo veći od perioda neizoliranog sistema. $Z a T_{b}=2,0 \mathrm{~s} \mathrm{i} \xi_{b}=10 \%$ ukupna deformacija $u_{b}=35,3 \mathrm{~cm}$ a poprečna sila $u$ bazi $V_{b}$ iznosi $35.9 \%$ težine građevine. Vidi se da promatranje konstrukcije kao krute daje točne rezultate, jer karakteristike vibracija s konstrukcijom od $\mathrm{T}_{\mathrm{b}}=2,0 \mathrm{~s}$ i $\xi_{\mathrm{b}}=10 \%$ su bliske vrijednostima $\mathrm{T}_{1}=2,024 \mathrm{~s}$ i iznosi $\xi_{1}$ $=9,65 \%$.Preciznost ove metode aproksimacijom krute konstrukcije osigurava sredstvo pomoću kojeg se određuju djelotvornost izolacije baze i deformacija izolatora.

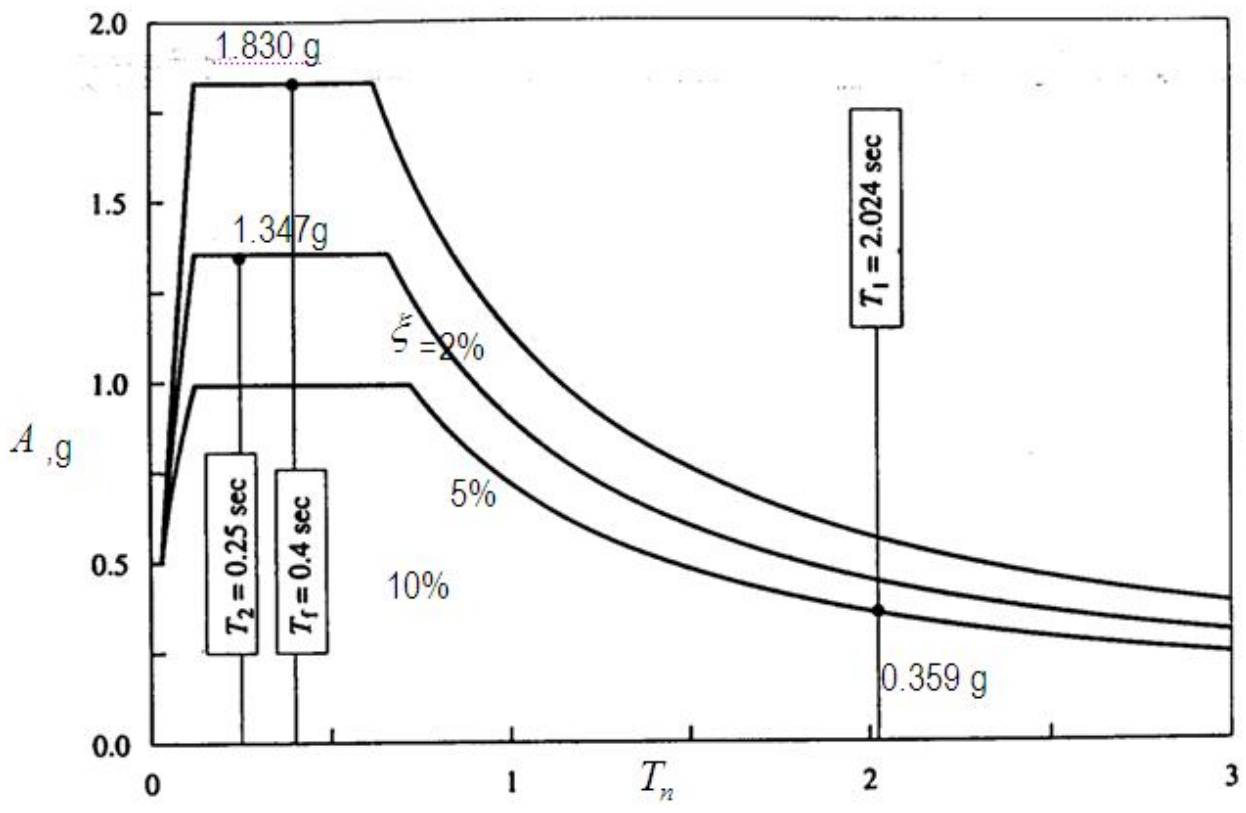

Slika 8 - Projektni spektar i ordinate spektra za izoliranu građevinu i građevinu s fiksnom bazom

Izolacijom baze, izolacijski oblik doprinosi gotovo cijelom odgovoru konstrukcije. Rezultat je sila reducirana od $183 \%$ težine konstrukcije na $36,5 \%$. Reduciranje sila zavisi od perioda fiksne baze i od projektnog spektra. Promatra se građevina s jednim katom i sistemom s izoliranom bazom primijenjenim na potres od $1985 \mathrm{u}$ Mexico City. 


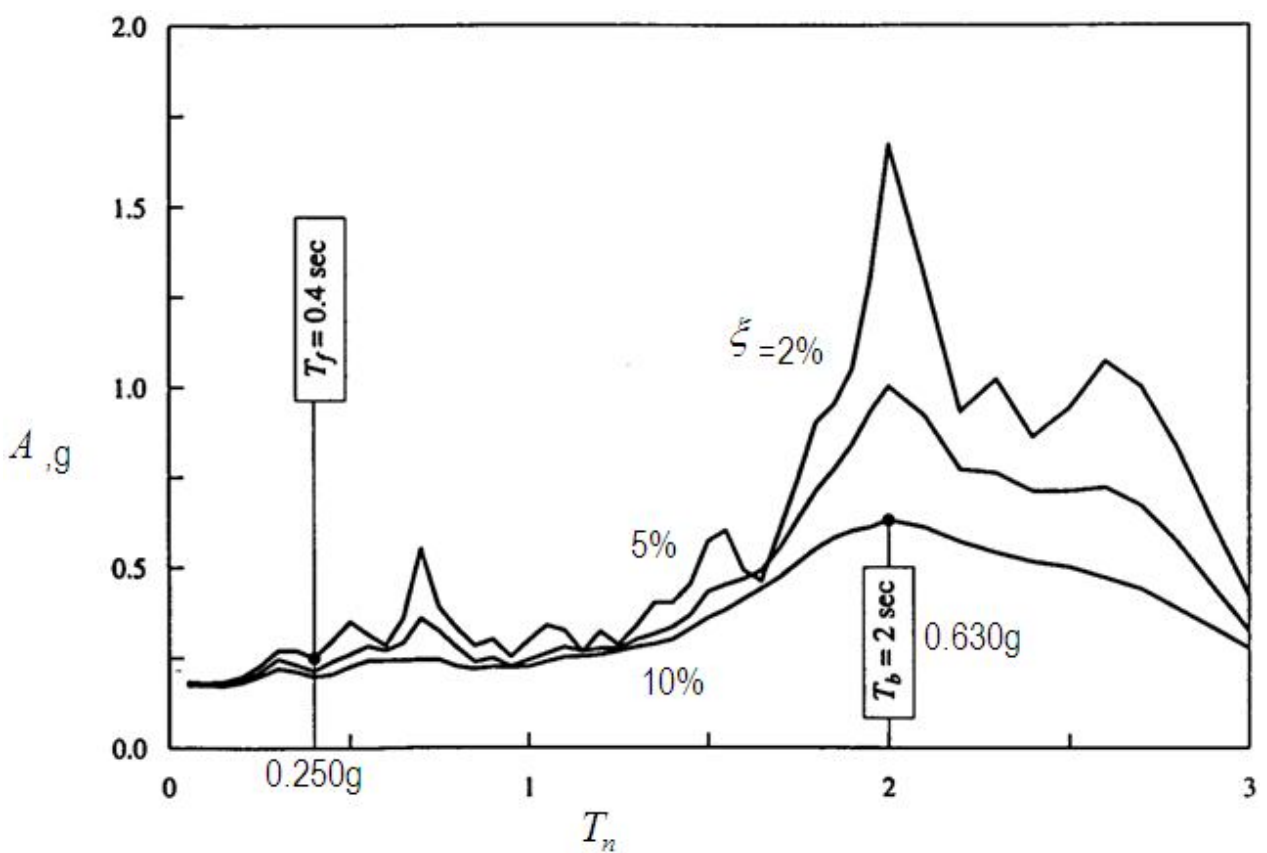

Slika 9 - Spektar pomaka (potres Mexica 1985.) za izoliranu građevinu i građevinu s fiksnom bazom

Na slici 9 se vidi da za fiksnu bazu pseudo ubrzanje iznosi $0.25 \mathrm{~g} \mathrm{i} 0.63 \mathrm{~g}$ za izoliranu bazu. Te spektralne vrijednosti odgovaraju prije definiranim karakteristikama za fiksnu bazu $T_{f}=0,4 \mathrm{~s}$ i $\xi_{f}=2 \%$ i za izoliranu bazu $T_{b}$ $=2,0 \mathrm{~s}$ i $\xi_{\mathrm{b}}=10 \%$. Sila u izoliranoj konstrukciji je 2,52 puta veća nego u fiksnoj bazi. U tom slučaju izolacija je beskorisna, nepotrebna.

Nadalje, promatrajući konstrukciju s relativno dugim periodom fiksne baze i kretanje tla prema projektnom spektru, pokazuje se da je mala učinkovitost izolacije baze.

Za vrijednosti za fiksnu bazu $T_{f}=2,0 \mathrm{~s}$ i $\xi_{f}=2 \%$ i za izoliranu bazu $T_{b}=2,0 \mathrm{~s}$ i $\xi_{b}=10 \%$ tj. kada je $T_{f}=T_{b}$ modalni odnosi prigušenja su: za prvioblik iznosi $\xi_{1}=4,5 \%$, a za drugi $\xi_{2}=12,64 \%$.

$\mathrm{U}$ suprotnosti s prethodnim sistemom konstrukcija se ne ponaša kao kruta u prvom obliku i period je izraz značajne fleksibilnosti konstrukcije. Drugi oblik u odnosu na djelovanje na učinkovitost potresne sile nije beznačajan. Prvi oblik ima vrijednost prigušenja od $4.5 \%$ i nije blizu prigušenja izoliranog sistema od $10 \%$.

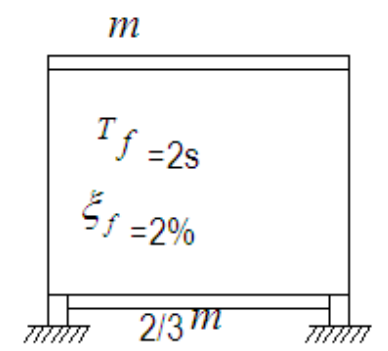

$$
T_{b}=2 \mathrm{~s}, \quad \xi_{b}=10 \%
$$

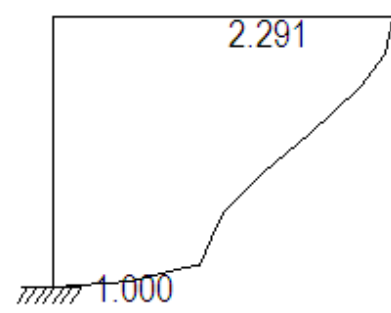

$T_{1}=2.664 \mathrm{~s}$

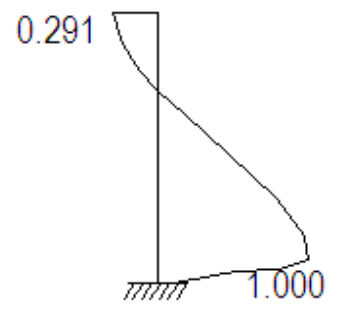

$T_{2}=0.949 \mathrm{~s}$

Slika 10 - Izolirana građevina, njezini oblici i periodi

$\mathrm{U}$ usporedbi s prethodnim sustavom odgovor drugog oblika moda je važan. Poprečna sila u bazi $\mathrm{Vb}$ iznosi $35 \%$ težine građevine. Budući da konstrukcija s fiksnom bazom ima vrijednost bazu $T_{f}=2,0 \mathrm{~s} \mathrm{i} \xi_{f}=2 \%$ poprečna sila u bazi $\mathrm{V}_{\mathrm{b}}$ iznosi $56,9 \%$ težine građevine. 


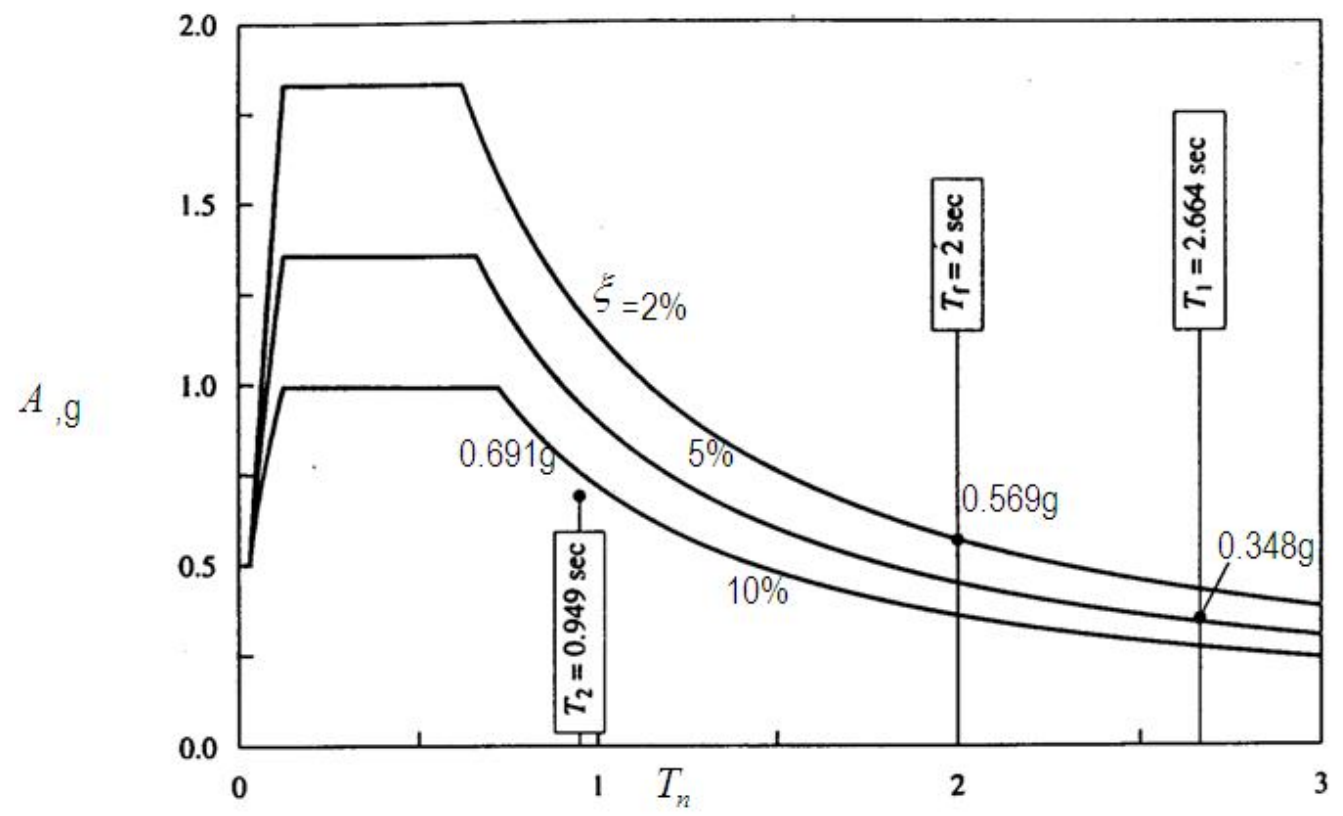

Slika 11 - Projektni spektar i ordinate spektra za izoliranu građevinu i građevinu s fiksnom bazom

Može se zaključiti da aproksimativna analiza bazirana na pretpostavci za krute konstrukcije nije točna za konstrukcije s relativno dugim periodom. Ova analiza zasnovana na elementima dinamike konstrukcija ukazuje da postoje situacije u kojima izolacija baze nije svrsishodna, dapače je štetna.

\section{Seizmička analiza armiranobetonskog okvira sa i bez izolacije baze [3]}

\subsection{Odabrana konstrukcija}

Obabrana je armiranobetonska okvirna konstrukcija (slika 12) tlocrtne površine 30x18 metara i visine 18 metara koja se sastoji se od 6 katova, svaki kat je visine 3 metra. Služi za smještaj opreme čiji proizvođači ograničavaju međukatni horizontalni pomak na vrijednost $h / 600$. Konstrukcijski elementi su stupovi, grede i stropne ploče od betona klase C25/30 i čelika RA 400/500. Dimenzije stupova su $30 \times 30 \mathrm{~cm}$, a greda $30 \times 50 \mathrm{~cm}$. Međukatna konstrukcija je sastavljena od križno armiranih ploča. Debljina ploče je $15 \mathrm{~cm}$.

Konstrukcija je opterećena vertikalnim opterećenjem i to stalnim i promjenjivim opterećenjem te horizontalnim potresnim opterećenjem čije je maksimalno ubrzanje 0,2g.

$U$ radu se provela izolacija konstrukcije elastomernim izolatorima te usporedba seizmičkog odgovora tako izolirane konstrukcije s istom koja je upeta u temeljnu konstrukciju. Odabrani tip izolatora je tip 2, usidren u svim smjerovima pomični elastomerni ležaj. Usidrenje se vrši pomoću trnova ili vijaka.

Bitne karakteristike konstrukcije su: materijal (beton C 25/30 i čelik RA 400/500), korisno opterećenje 2,5 $\mathrm{kN} / \mathrm{m}^{2}$, dimenzije greda $30 / 50 \mathrm{~cm}$ stupova $30 / 30 \mathrm{~cm}$.

Potresno opterećenje VIII zona intenziteta s ubrzanjem $0,2 \mathrm{~g}$. 


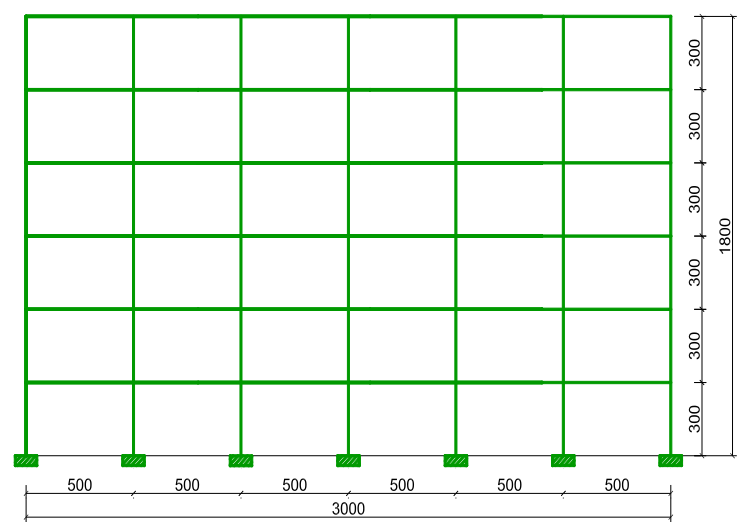

Slika 12 - Odabrani ab okvir

\subsection{Seizmičke analize}

Konstrukcija je modelirana programom Robot-Milenium. Provedene dinamičke seizmičke analize su linearne. Potres je modeliran spektralnom funkcijom prema EC8 (slika 13). U obzir su uzeta prva tri oblika i provedena je CQC kombinacija. Kod upete konstrukcije čvorovi modela na dnu stupova su takvima i modelirani, a kod izolirane su zadane opruge s izračunatim krutostima (vertikalnom i horizontalnom) odabranog izolatora. Za izolaciju, ispod svakog stupa, odabran je elastomerni ležaj POLIROL TIP2, usidren u svim smjerovima pomični elastomerni ležaj tlocrtnih dimenzija $300 \times 400 \mathrm{~mm}$, visine $1370 \mathrm{~mm}$, debljine elastomera $800 \mathrm{~mm}$, broj slojeva elastomera 100, debljine jednog sloja elastomera $8 \mathrm{~mm}$ i debljine lima $3 \mathrm{~mm}$. Površina ležaja je $\mathrm{A}=0,12 \mathrm{~m}^{2}$, modul posmika $\mathrm{G}=$ $1000 \mathrm{kN} / \mathrm{m}^{2}$, modul elastičnosti $\mathrm{E}=5,05 \times 10^{5} \mathrm{kN} / \mathrm{m}^{2}, \mathrm{~s}$ horizontalnom krutosti: $K h=\frac{G A}{T}=150 \mathrm{kN} / \mathrm{mi}$ vertikalnom krutosti $K v=\frac{E A}{T}=1,893 \times 10^{6} \mathrm{kN} / \mathrm{m}$

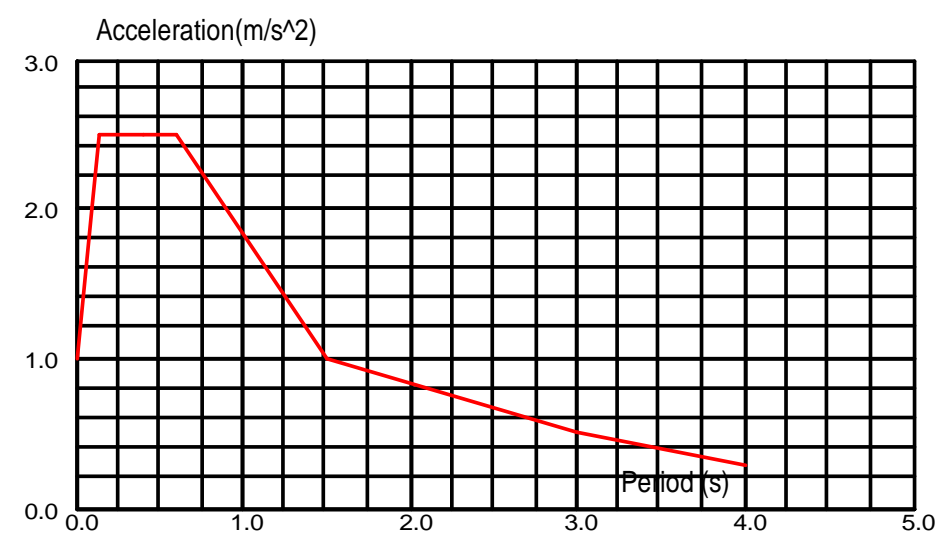

Slika 13 - Spektralna funkcija potresa prema EC8

Rezultate provedenih proračuna najbolje je sagledati u slici horizontalnih pomaka tijekom potresa upete i izolirane konstrukcije (slike 14 i 15) i njihovoj obradi u tablici 1., te usporedbom reznih sila i potrebne količine armature u stupovima (tablice 2 i 3 ). 


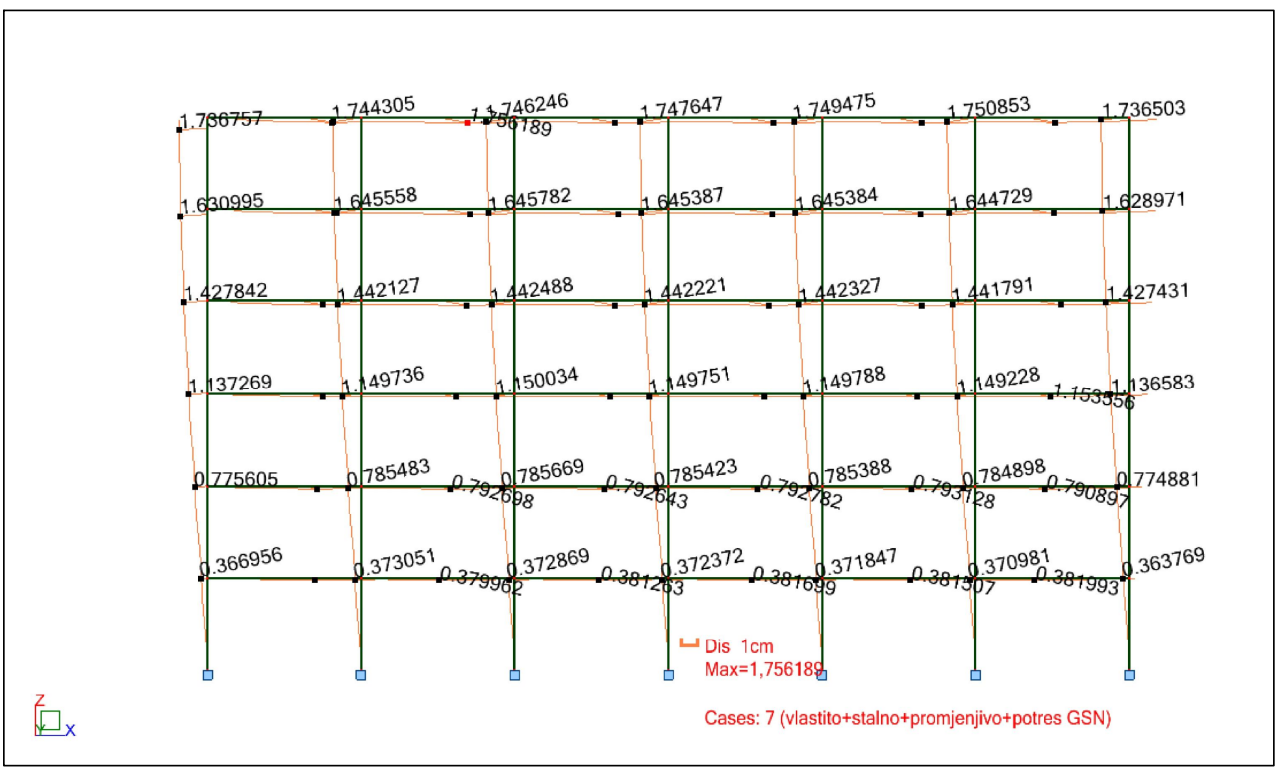

Slika 14 - Horizontalni pomak upete konstrukcije

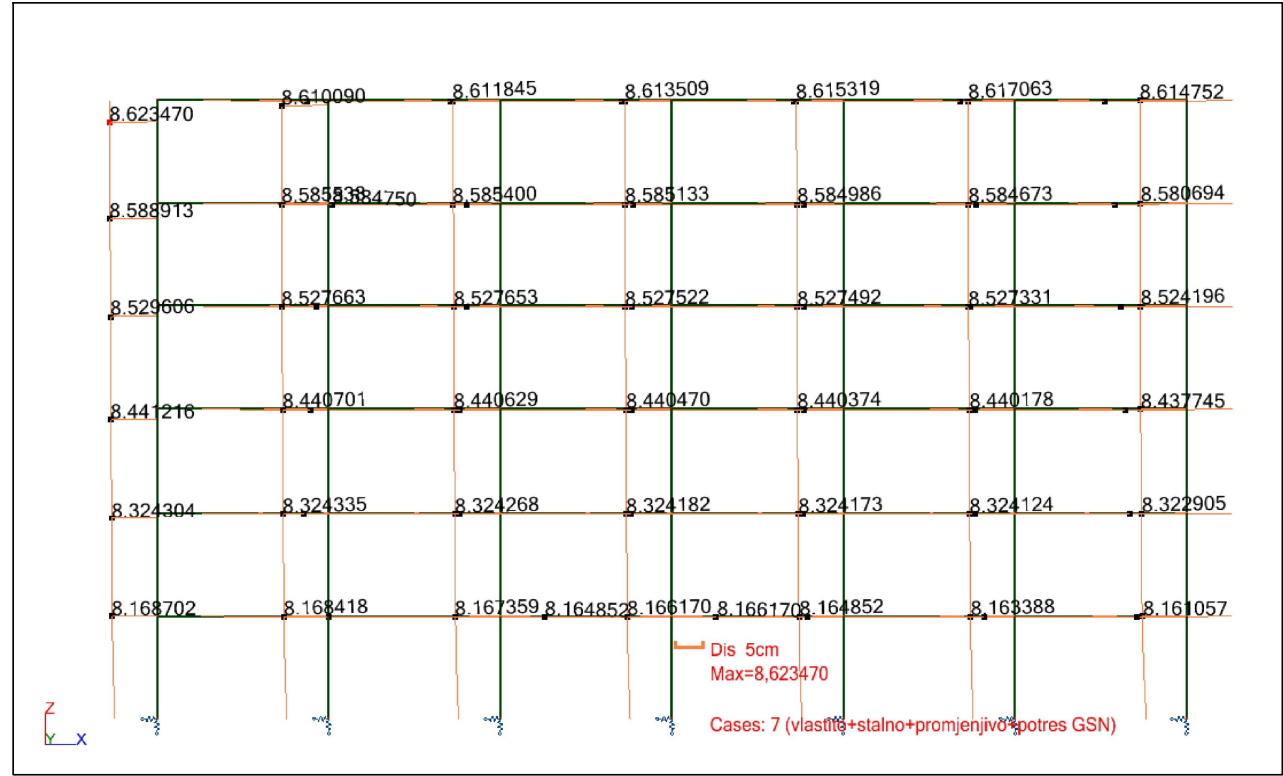

Slika 15 - Horizontalni pomak izolirane konstrukcije

Uspoređujući pomake upete i izolirane konstrukcije elastomernim ležajevima, zaključujemo da kod upete konstrukcije međukatni pomaci rastu do 1/3 visine konstrukcije, a zatim se lagano smanjuju. Deformacija ima smičući oblik.

U slučaju izolirane konstrukcije, elastomerni izolatori preuzimaju najveći dio pomaka dok se okvir ponaša kao kruti disk. Razlika odnosa međukatnih pomaka je izrazita. Izolirana konstrukcija ima u prosjeku 3 puta manje međukatne pomake. 
Tablica 1 - Horizontalni pomaci za obje konstrukcije

\begin{tabular}{|c|c|c|c|c|}
\hline Etaža & $\begin{array}{l}\text { UPETA } \\
\text { KONSTRUKCIJA } \\
\text { UX (cm) }\end{array}$ & $\begin{array}{l}\text { MEĐUKATNI } \\
\text { POMACI } \\
(\mathrm{cm})\end{array}$ & $\begin{array}{l}\text { IZOLIRANA } \\
\text { KONSTRUKCIJA } \\
\text { UX (cm) }\end{array}$ & $\begin{array}{l}\text { MEĐUKATNI } \\
\text { POMACI } \\
(\mathrm{cm})\end{array}$ \\
\hline 0 & 0,0 & \multirow{2}{*}{0,363} & 8,018132 & \multirow[b]{2}{*}{0,142} \\
\hline \multirow{2}{*}{1} & \multirow{2}{*}{0,362587} & & \multirow{2}{*}{8,160887} & \\
\hline & & 0,410 & & 0,162 \\
\hline 2 & \multirow[t]{2}{*}{0,772940} & & \multirow[t]{2}{*}{8,322491} & \\
\hline \multirow{2}{*}{3} & & 0,361 & & 0,115 \\
\hline & 1,134031 & 0,290 & 8,437058 & 0,086 \\
\hline \multirow[t]{2}{*}{4} & \multirow[t]{2}{*}{1,424411} & & \multirow[t]{2}{*}{8,523262} & \\
\hline & & 0,201 & & 0,056 \\
\hline 5 & 1,625630 & & 8,579575 & \\
\hline \multirow{2}{*}{6} & \multirow{2}{*}{1,733023} & 0,107 & \multirow{2}{*}{8,613541} & 0,034 \\
\hline & & & & \\
\hline
\end{tabular}

Tablica 2. Rezne sile u odabranim stupovima trećeg kata okvira

\begin{tabular}{|l|l|l|l|l|l|l|}
\hline \multirow{2}{*}{ Stup } & \multicolumn{3}{|l|}{ UPETA KONSTRUKCIJA } & \multicolumn{3}{l|}{ IZOLIRANA KONSTRUKCIJA } \\
\cline { 2 - 7 } & FX (kN) & FZ (kN) & MY (kNm) & FX (kN) & FZ (kN) & MY (kNm) \\
\hline 35 & & & & & & \\
\hline 35 & $-672,38$ & $-33,84$ & 50,54 & $-661,44$ & $-9,40$ & 13,94 \\
\hline
\end{tabular}

U tablicama 2 i 3 možemo vidjeti kako smo izoliranjem konstrukcije postigli znatnu redukciju momenata savijanja i poprečnih sila (oko 70\%) a zbog toga je bitno smanjena potrebna količina uzdužne i poprečne armature u odnosu na potrebnu količinu armature upete konstrukcije (tablica 3). 
Tablica 3 - Potrebna armatura u odabranim stupovima trećeg kata okvira

\begin{tabular}{|c|c|c|c|c|c|c|c|}
\hline \multicolumn{8}{|c|}{ TABLICA ARMATURE UPETE KONSTRUKCIJE } \\
\hline \multicolumn{2}{|c|}{ STUP } & $\begin{array}{l}\text { Msd } \\
{[\mathrm{kNm}]}\end{array}$ & $\begin{array}{l}N_{s d} \\
{[k N]}\end{array}$ & $\begin{array}{l}\mathrm{V}_{\mathrm{sd}} \\
{[\mathrm{kN}]}\end{array}$ & $\begin{array}{l}\text { KOLIČINA } \\
\text { POPREČNE } \\
\text { ARMATURE }\end{array}$ & \multicolumn{2}{|c|}{$\begin{array}{l}\text { KOLIČINA UZDUŽNE } \\
\text { ARMATURE }\end{array}$} \\
\hline & \multirow{2}{*}{$\begin{array}{l}\text { ČVOR } \\
16\end{array}$} & \multirow[b]{2}{*}{50,54} & \multirow[b]{2}{*}{$-672,38$} & \multirow[b]{2}{*}{$-33,84$} & \multirow{2}{*}{$\begin{array}{l}\Phi 10 / 22 \mathrm{~cm} \\
\mathrm{~m}=2 \\
1,58 \mathrm{~cm}^{2}\end{array}$} & $8 Ф 16$ & $8 Ф 16$ \\
\hline & & & & & & $15,96 \mathrm{~cm}^{2}$ & $15,96 \mathrm{~cm}^{2}$ \\
\hline & \multirow{2}{*}{$\begin{array}{l}\text { ČVOR } \\
23\end{array}$} & \multirow[b]{2}{*}{53,15} & \multirow[b]{2}{*}{$-663,44$} & \multirow[b]{2}{*}{$-33,84$} & \multirow{2}{*}{$\begin{array}{l}\Phi 10 / 22 \mathrm{~cm} \\
\mathrm{~m}=2 \\
1,58 \mathrm{~cm}^{2}\end{array}$} & $8 Ф 16$ & $8 Ф 16$ \\
\hline$\stackrel{\varrho}{m}$ & & & & & & $15,96 \mathrm{~cm}^{2}$ & $15,96 \mathrm{~cm}^{2}$ \\
\hline \multicolumn{8}{|c|}{$T A B L I C A$} \\
\hline \multicolumn{2}{|c|}{ STUP } & $\begin{array}{l}\text { Msd } \\
{[\mathrm{kNm}]}\end{array}$ & $\begin{array}{l}N_{s d} \\
{[k N]}\end{array}$ & $\begin{array}{l}V_{\text {sd }} \\
{[k N]}\end{array}$ & $\begin{array}{l}\text { KOLIČINA } \\
\text { POPREČNE } \\
\text { ARMATURE }\end{array}$ & \multicolumn{2}{|c|}{$\begin{array}{l}\text { KOLIČINA UZDUŽNE } \\
\text { ARMATURE }\end{array}$} \\
\hline & \multirow{2}{*}{$\begin{array}{l}\text { ČVOR } \\
16\end{array}$} & \multirow[b]{2}{*}{13,94} & \multirow[b]{2}{*}{$-661,44$} & \multirow[b]{2}{*}{$-9,40$} & \multirow{2}{*}{$\begin{array}{l}\Phi 10 / 22 \mathrm{~cm} \\
\mathrm{~m}=2 \\
1,58 \mathrm{~cm}^{2}\end{array}$} & $6 Ф 16$ & $6 Ф 16$ \\
\hline & & & & & & $11,22 \mathrm{~cm}^{2}$ & $11,22 \mathrm{~cm}^{2}$ \\
\hline & \multirow{2}{*}{$\begin{array}{l}\text { ČVOR } \\
23\end{array}$} & \multirow[b]{2}{*}{18,38} & \multirow[b]{2}{*}{$-652,50$} & \multirow[b]{2}{*}{$-9,40$} & \multirow{2}{*}{$\begin{array}{l}\Phi 10 / 22 \mathrm{~cm} \\
\mathrm{~m}=2 \\
1,58 \mathrm{~cm}^{2}\end{array}$} & $6 Ф 16$ & $6 Ф 16$ \\
\hline 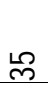 & & & & & & $11,65 \mathrm{~cm}^{2}$ & $11,65 \mathrm{~cm}^{2}$ \\
\hline
\end{tabular}

\section{Zaključak}

Iz usporedbe provedenih proračuna evidentno je da je, na ovaj način izolirana konstrukcija, zaštićena od potresa. Dinamički gledano, koncept je optimalan i trebalo bi ga primjenjivati u svim zemljama s izraženim seizmičkim potencijalom. Čemu onda dileme i zašto je se ovakav način zaštite tako rijetko primjenjuje?

Dileme su rezultat male horizontalne krutosti izolatora i mogućnosti da u jačem potresu budu oštećeni i plastificirani. Mala horizontalna krutost dovodi do velikih apsolutnih pomaka konstrukcije pa su problem dilatacije i sudaranje susjednih konstrukcija. Plastifikacija izolatora nameće pitanje kako oštećen izolator zamijeniti nakon jakog potresa.

Ako se ovi problemi riješe istraživanjem i osiguranjem pune elastičnosti izolatora u potresu, onda je ovaj način zaštite konstrukcija od potresa, barem što se dinamike konstrukcija tiče, optimalan za konstrukcije umjerenih katnosti i one koje oko sebe nemaju druge građevine.

\section{Literatura}

[1] Cristopoulos, C. A. Principles off Passive Suplement Damping and Seismic Isolation, IUSS Press 2006

[2] Naeim Farzad, Kelly, James M. Design of Seismic Isolated Structures - From Theory to Practice, John Wiley, 1999.

[3] Mitrović, S., Izoliranje građevina u uvjetima djelovanja potresa, diplomski rad, Građevinski fakultet Osijek, 2005,78 str.

[4] Tomičić, l., Betonske konstrukcije - odabrana poglavlja, Školska knjiga, Zagreb 1996 